\title{
Valorization of Date Pits as an Effective Biosorbent for Remazol Brilliant Blue Adsorption from Aqueous Solution
}

\author{
A. Thiam, ${ }^{1,2}$ K. Tanji $\mathbb{D},{ }^{1}$ O. Assila $\mathbb{D},{ }^{1}$ M. Zouheir $\mathbb{D}^{1},{ }^{1}$ Redouane Haounati, ${ }^{2}$ A. Arrahli $\left(\mathbb{D},{ }^{3}\right.$ \\ A. Abeid, ${ }^{4}$ S. Lairini, ${ }^{1}$ R. Bouslamti, ${ }^{1}$ F. Zerouq, ${ }^{1}$ and A. Kherbeche ${ }^{1}$ \\ ${ }^{1}$ Laboratory of Catalysis Process Materials and Environment, School of Technology, University Sidi Mohamed Ben Abdellah, \\ Fes, Morocco \\ ${ }^{2}$ Physical Chemistry and Environment Team, Faculty of Science, Ibn Zohr University, Agadir, Morocco \\ ${ }^{3}$ Euromed Research Center, National Institute of Applied Sciences, Euro-Mediterranean University of Fez, Fes, Morocco \\ ${ }^{4}$ Laboratory Food Microbiology Biotechnology and Environment, ISET, Rosso, Mauritania \\ Correspondence should be addressed to K. Tanji; karimtanji1992@gmail.com
}

Received 24 February 2020; Revised 15 July 2020; Accepted 24 August 2020; Published 8 October 2020

Academic Editor: José Morillo

Copyright (C) 2020 A. Thiam et al. This is an open access article distributed under the Creative Commons Attribution License, which permits unrestricted use, distribution, and reproduction in any medium, provided the original work is properly cited.

\begin{abstract}
In this work, the adsorption of Remazol Brilliant Blue (RBB) over raw date pits (RDPs) as an inexpensive adsorbent has been examined. In addition, all parameters such as the adsorbent mass, solution $\mathrm{pH}, \mathrm{RDP}$ particle size, RBB initial concentration, and temperature on the adsorption of $\mathrm{RBB}$ influencing the adsorption procedure were studied to provide fundamental information of the adsorption equilibrium. The characterization of RDP material is investigated by X-ray diffraction (XRD), scanning electron microscopy (SEM), and Fourier-transform infrared spectroscopy (FTIR). Based on the calculation, the kinetic rate of the adsorption was well modeled by pseudo-second-order and Langmuir isotherm. Surface functional groups of RDP have substantially been influenced by the adsorption characteristics of RBB. The capacity of the adsorption has achieved $105 \mathrm{mg} / \mathrm{g}$ and a removal efficiency of $90.4 \%$ at $1.5 \mathrm{~g} / \mathrm{L}$ RDP mass, $40 \mathrm{mg} / \mathrm{L}$ initial dye concentration, $\mathrm{pH}$ 2, temperature of $328 \mathrm{~K}, 40 \mu \mathrm{m}$ particle size, and contact time of $50 \mathrm{~min}$. The capacity of the adsorption could reach $198 \mathrm{mg} / \mathrm{g}$ by increasing the ionic strength of RBB solution. Desorption tests showed that RDP adsorbent has the disadvantage of losing efficiency while reusing for many cycles. However, it still abundant and inexpensive. Therefore, RDP can be used as a potential low-cost bioabsorbent for the elimination of RBB from wastewater.
\end{abstract}

\section{Introduction}

Pollution refers to the deterioration of the environment by unnatural materials, causing the disappearance of several species of animals, plants, as well as the appearance of new phenomena, which has harmful effects on human health, including global warming [1-3]. The effects of this pollution affect not only the air and the soil, but also a large part of the water. Dyes are used in many industrial sectors, such as textiles, paper, leather, food, and cosmetic industries [4].Moreover, these industries consume huge quantities of water. Once those dyes are released, they cause significant damage to human health such as the mutagenic and carcinogenic effects [5-8] and changes in the aquatic environment [9] when they are discharged into the environment without or with insufficient treatment [10-12]. To reduce the impact of this pollution, several techniques have been developed and tested in the treatment of effluents loaded with dyes, namely, biological process [13], coagulation/flocculation [14], photodegradation [15-18], ozonation $[19,20]$, oxidation $[21,22]$, and membrane separation [23-25]. The adsorption technique is considered as one of the most effective methods that has been successfully adopted for removing dyes from wastewater [26-31] due to its low cost and availability. Allowing easy removal of dyes from aqueous solutions over different materials and on activated carbon in particular [32] has always been the subject of much work [33,34]. Many adsorbents have been 
investigated for the removal of dyes in recent years [35] such as clay [36, 37], layered double hydroxides [38], metal oxides [39], goethite modified natural [40], and sediments [41, 42]. The activated carbon has a high cost. Hence, the need to look for cheaper, effective, and natural available adsorbent is therefore interesting [43]. Bioadsorbent materials have been proposed as alternative adsorbents for dyes. Especially, RDPs have received considerable attention for its properties, such as low cost, natural availability, and no threat to the environment. The fruit of the date palm is composed of a fleshy pericarp and seed. Pits of date palm (seed) are a waste product of many date fruit-processing plants producing pitted dates, date powders, date syrup, date juice, chocolatecoated dates, and date confectionery [44]. In addition, the $\mathrm{RDP}$ are very widely distributed and abundant, which make them the promising environmental adsorbents that can be used in industrial processes [3]. Javid et al. have studied the removal of bisphenol $\mathrm{A}$ and nonylphenol from aqueous solutions using carbonized date pits modified with $\mathrm{ZnO}$ nanoparticles, and they found maximum removal efficiency under optimal conditions was $95 \%[45,46]$. However, adsorption of RBB onto the RDP was not fully investigated [43]. Therefore, the objective of this work is to investigate the physics and chemical properties of RDP bioadsorbent using multiple methods such as X-ray diffraction (XRD), scanning electron microscopy (SEM), and Fourier-transform infrared spectroscopy (FTIR) and then to evaluate the effectiveness of using RDP as natural eco-friendly and low-cost bioadsorbent for the removal of $\mathrm{RBB}$ in aqueous media. Moreover, various parameters influencing the adsorption procedure of RBB adsorption on the RDP bioadsorbent, such as the adsorbent mass, solution $\mathrm{pH}$, RDP particle size, and RBB initial concentration, were studied. On the other hand, the ionic strength effect using $\mathrm{BaCl}_{2}$ on the adsorption equilibrium is important to highlight as well.

\section{Materials and Methods}

2.1. Preparation of RDP. Moroccan dates were shelled, and the pits were collected and sorted in order to remove the impurities and then dried at a temperature of $110^{\circ} \mathrm{C}$ in the oven for 24 hours. Then, the bioadsorbent was ground in a grinder and sieved in order to obtain particles of the same size with a diameter of $40,63,125$, and $200 \mu \mathrm{m}$. RDP contains an approximate percentage of hemicellulose, lignin, cellulose, and carbohydrates [3].

2.2. Adsorbate. The dye considered in this study is Remazol Brilliant Blue (RBB) analytical grade purchased for SigmaAldrich, it has the chemical formula $\mathrm{C}_{22} \mathrm{H}_{16} \mathrm{~N}_{2} \mathrm{Na}_{2} \mathrm{O}_{11} \mathrm{~S}_{3}$, and its maximum absorption band is located at the wavelength of $590 \mathrm{~nm}$. The main problems associated with RBB dye in textile wastewaters are resistant to biodegradation, highly visible due to its bright color, even in very low concentration of dye $(<1 \mathrm{mg} / \mathrm{L})$ in the effluent, and very toxic difficult to remove by traditional methods.

2.3. Adsorption Study. In this study, a stock solution was prepared from the RBB dye. The adsorption study was carried out by using $1 \mathrm{~g}$ of RDP mixed with a solution of RBB at room temperature under continuous stirring in a batch system. In order to investigate the kinetic adsorption, several samples were collected each $5 \mathrm{~min}$ to measure its concentration using UV-visible spectrophotometer (VR-2000) at a wavelength of $590 \mathrm{~nm}$. Nevertheless, before the measure, the suspension was centrifuged to separate the natural adsorbent from the RBB liquid. During the adsorption experiment, $\mathrm{HCl}(0.5 \mathrm{M})$ and $\mathrm{NaOH}(0.5 \mathrm{M})$ from Sigma-Aldrich were used to adjust the $\mathrm{pH}$ solution.

The RBB removal was calculated using following formula $[43,47]$ :

$$
\operatorname{removal}(\%)=\frac{\left(C_{0}-C_{t}\right)}{C_{0}} \times 100,
$$

where $C_{0}$ and $C_{t}$ are the concentration of RBB at $t=0$ and at $t \neq 0$, respectively.

The adsorption capacity of RDP for RBB removal was obtained by applying the following equation [48]:

$$
q_{e}=\frac{\left(C_{0}-C_{e}\right)}{m} \times V,
$$

where $q_{e}(\mathrm{mg} / \mathrm{g})$ is the adsorption capacity at equilibrium, $C_{0}$ $(\mathrm{mg} / \mathrm{L})$ is the initial concentration of RBB, $C_{e}(\mathrm{mg} / \mathrm{L})$ is the equilibrium concentration of RBB, $V(\mathrm{~L})$ is the RBB solution volume, and $m(\mathrm{~g})$ is the RDP mass.

2.4. Characterization Techniques. The X-ray diffraction ( $\mathrm{X}^{\prime}$ PERT PRO) equipped with a detector operating at $40 \mathrm{kV}$ and $30 \mathrm{~mA}$ with $\mathrm{Cu} \mathrm{K \alpha}$ radiation $(\lambda=1.540598 \AA)$, infrared spectroscopy (VERTEX 70), and scanning electron microscopy (QUANTA 200) were used to identify the composition and the morphology of adsorbents materials to explore the chemical composition of RDP.

\section{Results and Discussion}

\subsection{RDP Characterization}

3.1.1. X-Ray Diffraction (XRD). The X-ray pattern of RDP data is given in Figure 1. It can be observed that diffractogram of bioadsorbent RDP does not exhibit a horizontal basic line and displayed the presence of little diffraction peaks. The broad diffraction peak located between $20^{\circ}$ and $25^{\circ}$ could be ascribed to carbon species according to the native cellulose $\left(\mathrm{C}_{6} \mathrm{H}_{12} \mathrm{O}_{6}\right)$ and to xylane dehydrate $\left(\mathrm{C}_{10} \mathrm{H}_{12} \mathrm{O}_{9} \cdot 2 \mathrm{H}_{2} \mathrm{O}\right)$ [49]. On the contrary, the other few small diffraction peaks may be attributed to the presence of a small amount of crystalline matter. Therefore, this result indicated that the major part of the matter is amorphous.

3.1.2. Scanning Electron Microscopy (SEM). SEM analysis is made on RDP before adsorption (Figures 2 (a) and 2(b)). The material has a smooth porous surface, indicating a good possibility of trapping RBB adsorption on the adsorbent surface. On the contrary, after the RBB is adsorbed into RDP biomaterials, the SEM observation shows the surface of RDP charged with RBB displaying a rough and corroded surface 


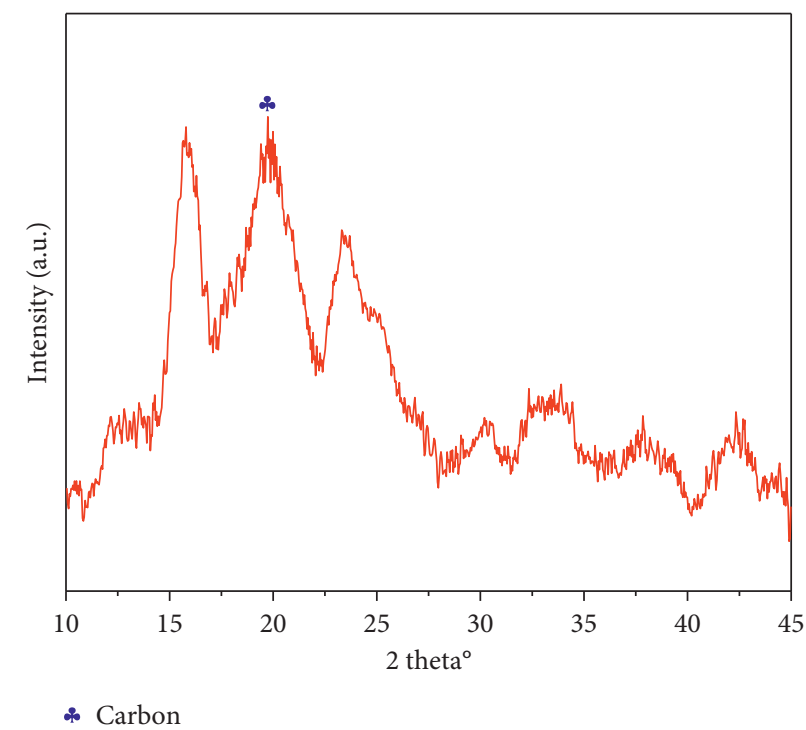

FIGURE 1: XRD pattern of RDP.

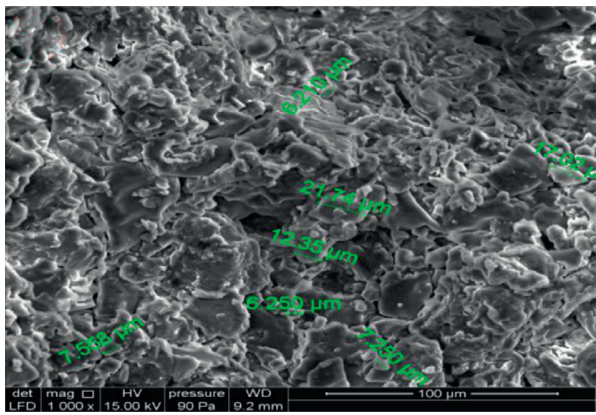

(a)

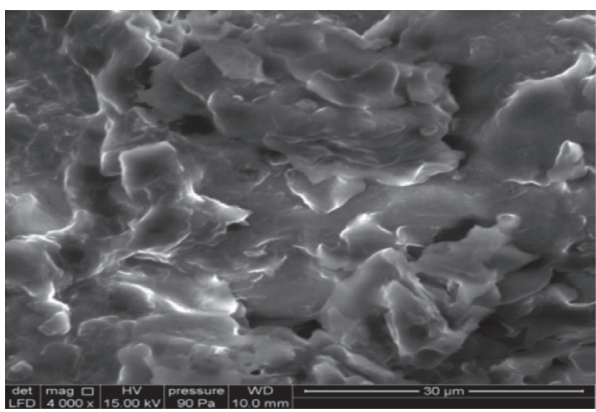

(c)

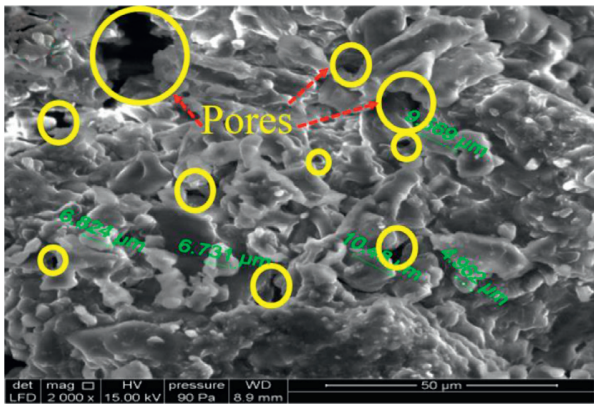

(b)

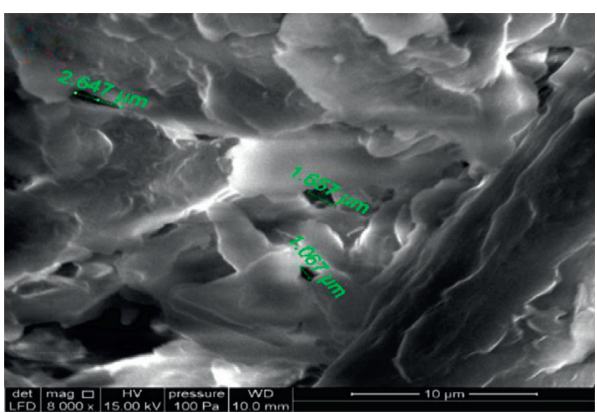

(d)

FIGURE 2: Scanning electron microscopy (SEM) images of RDP: (a, b) before adsorption; (c, d) after adsorption.

due to the coverage of the pores by the RBB dye molecules adsorbed in Figures 2(c) and 2(d). This result indicated that the raw date pits (RDPs) could be an efficient bioadsorbent to remove hazardous dyes in the wastewater.

3.1.3. Fourier-Transform Infrared Spectroscopy. The RDP infrared spectrum studied in this work (Figure 3) allows us to observe a characteristic broad band around $3400 \mathrm{~cm}^{-1}$ corresponding to the $\mathrm{O}-\mathrm{H}$ stretching vibrations. The
$1000 \mathrm{~cm}^{-1}$ band confirms the existence of an alcohol, and $2800 \mathrm{~cm}^{-1}$ corresponds to the valence vibrations of $\mathrm{C}-\mathrm{H}$ hybridized $\mathrm{sp}^{3}$ that can be attributed to the presence of native cellulose $\left(\mathrm{C}_{6} \mathrm{H}_{12} \mathrm{O}_{6}\right)$ and xylane dehydrate $\left(\mathrm{C}_{10} \mathrm{H}_{12} \mathrm{O}_{9} \cdot 2 \mathrm{H}_{2} \mathrm{O}\right)$, which was already confirmed by XRD analysis. In addition, the band located at $400 \mathrm{~cm}^{-1}$ corresponds to the deformation vibrations of $\delta \mathrm{C}-\mathrm{H}$ and the band at $1600 \mathrm{~cm}^{-1}$ according to the deformation vibrations of $\delta \mathrm{O}-$ $\mathrm{H}$. The analysis of this graph shows that our RDP biomaterial is an organic compound essentially containing the carbon 


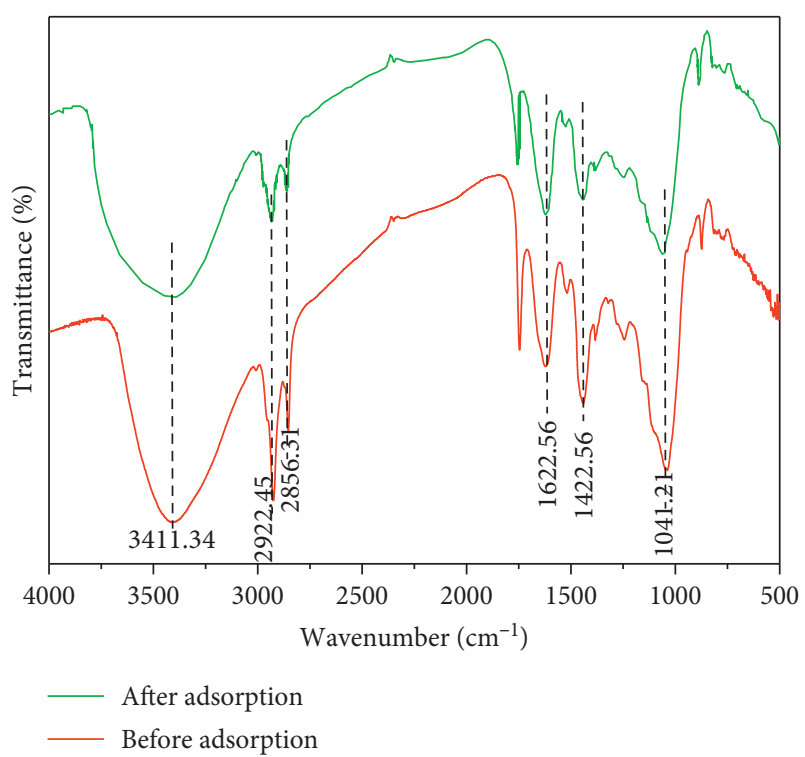

FIgURE 3: Infrared spectrum of RDP before and after RBB adsorption.

atom, hydrogen, and oxygen [50-52]. After adsorption of RBB (Figure 3), the functional groups present on the surfaces of RDP show band shifting for possible involvement of hydroxyl groups around the broad peak at $3400 \mathrm{~cm}^{-1}$. The broad peak shifted to $3411 \mathrm{~cm}^{-1}$. The initial peak at $2922 \mathrm{~cm}^{-1}$ was shifted to $2928 \mathrm{~cm}^{-1}$ and showed an alkane group was bonded to $\mathrm{C}-\mathrm{H}$ stretch. The strong band at $1622 \mathrm{~cm}^{-1}$ was shifted and corresponding to the amine group with $\mathrm{N}-\mathrm{H}$ bond. Therefore, the diminished peaks showed that all the functional groups are completely involved in the adsorption process of RBB over RDP [53-55].

\subsection{Effect of Different Parameters on the Adsorption Efficiency}

3.2.1. Initial Solution $\mathrm{pH}$ Effect. The $\mathrm{pH}$ definitely affects the adsorption of the dye. In order to determine the adsorption behavior of the RBB dye under different $\mathrm{pH}$ values (from 2.3 to 9.03), a series of adsorption experiments were carried out using $40 \mathrm{mg} / \mathrm{L}$ of RBB, $1 \mathrm{~g} / \mathrm{L}$ RDP, particle size of $63 \mu \mathrm{m}$, at room temperature, and stirring at $250 \mathrm{rpm}$. Figure 4 shows that there is a variation in the RBB removal as a function of $\mathrm{pH}$. Accordingly, when the $\mathrm{pH}$ raises from 2 to 9 , the adsorption removal decreases from 86.5 to $64.8 \%$. This is due to the neutralization of the negative charge on the surface of the adsorbents by the charged dye molecule [56]. An increased diffusion process facilitates the fixation of the dye on the active sites of the adsorbents [57]. Figure 5 shows that the $\mathrm{pH}_{\mathrm{pzc}}$ of raw $\mathrm{RDP}$ is 6.01 [58].

3.2.2. Effect of RDP Mass. This study makes it possible to evaluate the influence of the adsorbent mass, in order to determine the optimal mass, which coincides with a better dispersion of the adsorbent particles (RDPs). Figure 6(a) below represents the variation in the adsorption capacity as a function of time and of the adsorbent mass, which varies

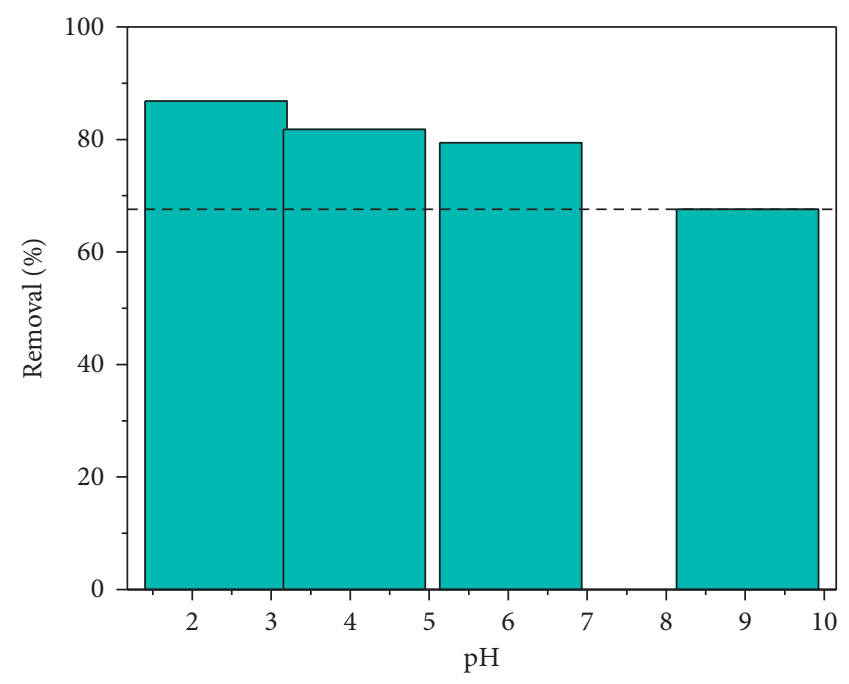

Figure 4: pH solution effect on the RBB adsorption.

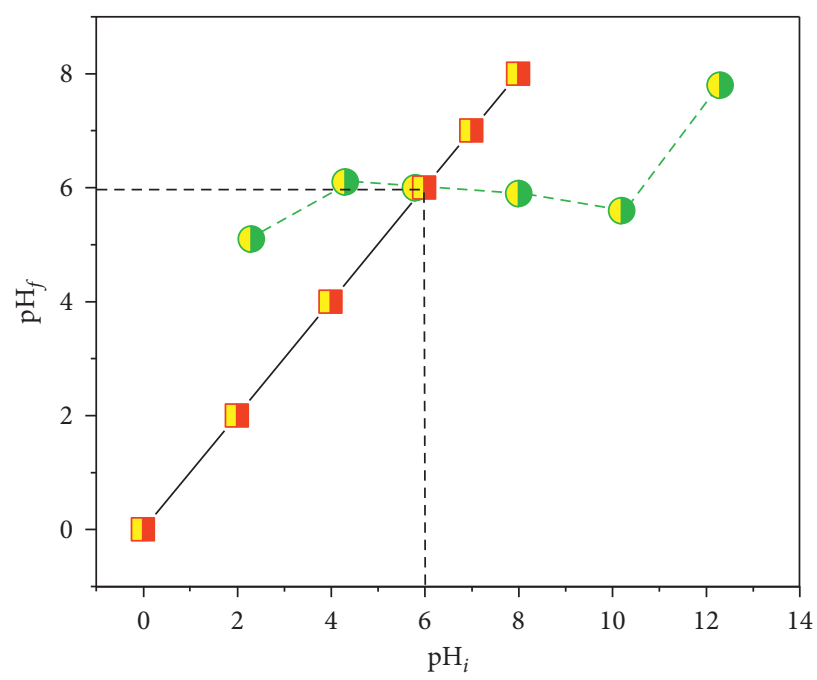

Figure 5: $\mathrm{pH}_{\mathrm{pzc}}$ of raw date pit.

from 0.5 to $3 \mathrm{~g}$ using $40 \mathrm{mg} / \mathrm{L}$ of RBB, particle size of $63 \mu \mathrm{m}$, $\mathrm{pH} \mathrm{4}$, at room temperature, and stirring at $250 \mathrm{rpm}$. Figure 6(b) shows an increase in the removal with the increase in RDP mass from $63 \%$ to $82.1 \%$ when the mass of adsorbent raises from 0.5 to $3 \mathrm{~g}$. Conversely, there is a decrease in the adsorption capacity from 104.2 to $58 \mathrm{mg} / \mathrm{g}$. The increase or the decrease in the first $30 \mathrm{~min}$ was fast and then followed by the flat curve proving the saturation of the adsorbent. The crossing point of the removal and the adsorption capacity correspond to the optimal mass of $1.5 \mathrm{~g}$ (Figure 6(b)). These results can be explained by an increase in the active sites when the masses are large. Consequently, the probability of contact between the RBB molecule and the site of the adsorbent support also increases [59].

3.2.3. Effect of Initial RBB Concentration. This study makes it possible to reach the maximum values of adsorption capacity of RBB, which represents the saturation of all the 

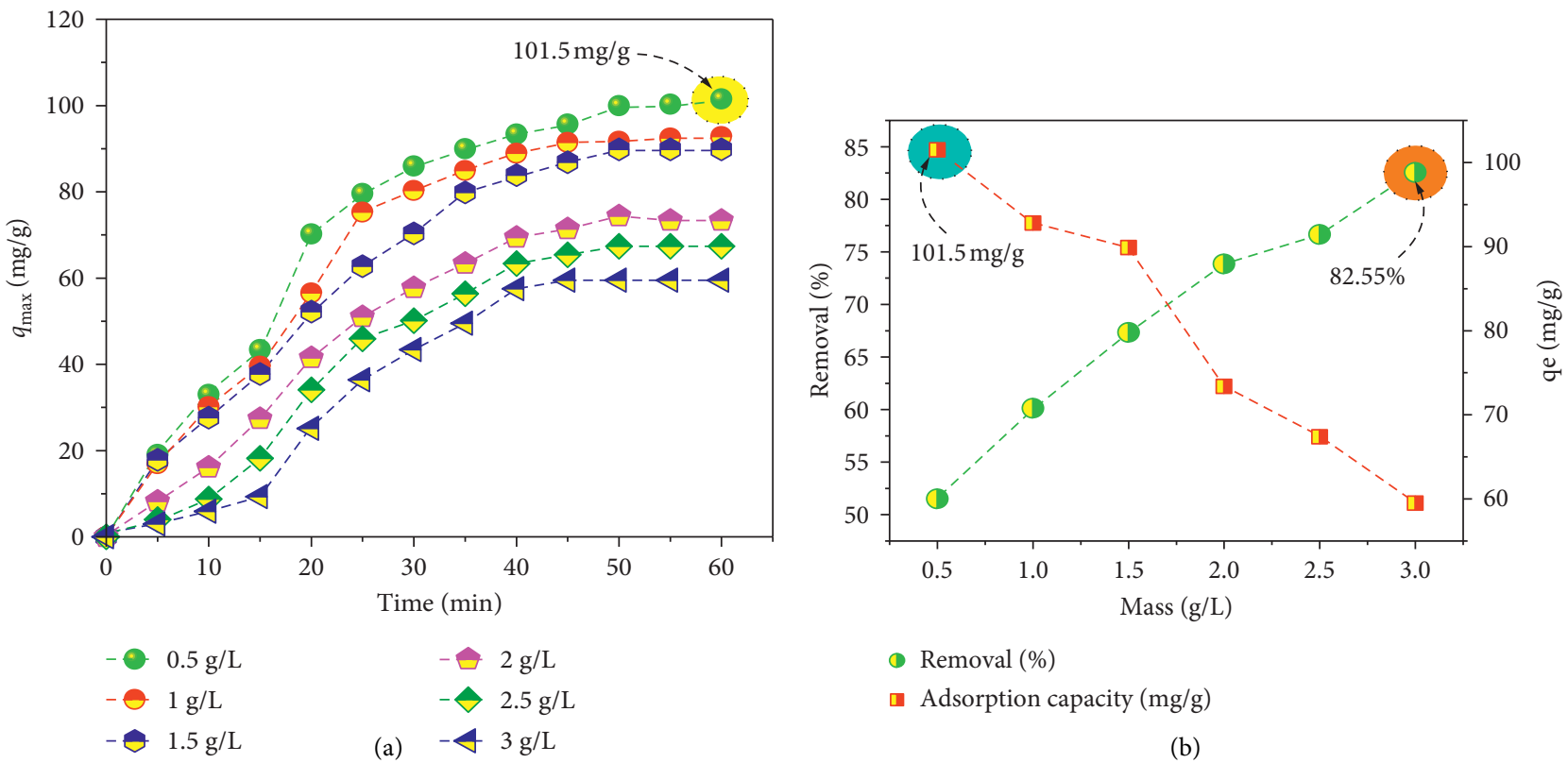

FIgURE 6: RDP mass effect on the RBB adsorption (a) and the optimal RDP mass during the adsorption phenomenon (b).

active sites available on the surface of the adsorbent. The effect of the initial RBB concentration was studied at different initial RBB concentrations varying between 10 and $60 \mathrm{mg} / \mathrm{L}$ using $1 \mathrm{~g} / \mathrm{L}$ RDP, particle size of $63 \mu \mathrm{m}$, and solution $\mathrm{pH} \mathrm{4}$, at room temperature and stirring at $250 \mathrm{rpm}$. According to Figure 7(a), there is a fairly rapid increase in the adsorption capacity in the area of high concentrations. The increase or the decrease in the first $30 \mathrm{~min}$ was fast and then followed by the flat curve proving the saturation of the adsorbent. This absorption capacity continues to decrease with the decrease in the RBB initial concentration $[60,61]$. In summary, the adsorption capacity of RBB on the adsorbent increases from 66.9 to $105.6 \mathrm{mg} / \mathrm{g}$ when the initial concentration of RBB increases from $10 \mathrm{mg} / \mathrm{L}$ to $60 \mathrm{mg} / \mathrm{L}$. These results could be explained by the existence of strong interactions between the RDP surface and the RBB. The saturation appears when the active sites are totally occupied on the adsorbent surface [62]. Plotting the adsorption capacity, and the removal as a function of the equilibrium concentrations, shows an intersection point of two curves, which corresponds to the optimal concentration which is $40 \mathrm{mg} / \mathrm{L}$, as shown in Figure 7(b).

3.2.4. Effect of the Particle Size. In order to study the effect of RDP particles sizes, a series of experiments were performed with different particles sizes from 40 to $200 \mu \mathrm{m}$ using $40 \mathrm{mg} /$ $\mathrm{L}$ of RBB, $1 \mathrm{~g} / \mathrm{L} \mathrm{RDP}, \mathrm{pH} 4$, at room temperature, and stirring at $250 \mathrm{rpm}$. Figure 8 illustrates that decreasing particles size enhanced the adsorption capacity: the $40 \mu \mathrm{m}$ particle size has the highest RBB removal (95\%). Others mesh presented lower removal between $72 \%$ and $85.6 \%$. Although the $200 \mu \mathrm{m}$ size showed a slow adsorption about $49.64 \%$ at $60 \mathrm{~min}$, this evolution could be explained by the link between the effective surface area of RDP particles and the adsorption efficiency in which the small particles have a large surface area exposed to adsorption and hence high adsorption [63].

3.2.5. Effect of Temperature. The adsorption removal of RBB on the RDP adsorbent increases from 82.21 to $94 \%$ when the temperature rises from $298 \mathrm{~K}$ to $328 \mathrm{~K}$ using $40 \mathrm{mg} / \mathrm{L}$ of RBB, $1 \mathrm{~g} / \mathrm{L} \mathrm{RDP}$, particle size of $63 \mu \mathrm{m}, \mathrm{pH} 4$, and stirring at $250 \mathrm{rpm}$ (Figure 9). This small increase in adsorption removal indicates that the adsorption process is endothermic [64]: the system at low temperatures requires a high energy to reach equilibrium although this system at high temperatures requires less energy to reach equilibrium. The effect of temperature on the removal is in agreement with the results found by the use of a biomaterial based on RDP [60]. The slight increase in the removal as a function of temperature can be explained as follows: (i) the increase in the active sites on the RDP surface; (ii) the increasing temperature increases the mobility of RBB, inducing a swelling effect in the internal structure of RDP, which facilitated the penetration of RBB further [56].

3.2.6. Adsorption of RBB over RDP under Optimum Conditions. The adsorption of the RBB dye solution was tested by applying the optimal conditions which are RDP mass $1.5 \mathrm{~g} / \mathrm{L}, \mathrm{RBB}$ concentration $40 \mathrm{mg} / \mathrm{L}$, particle size of $40 \mu \mathrm{m}$, temperature $328 \mathrm{~K}$, and the $\mathrm{pH} 2$. Figure 10 illustrates the evolution of the adsorption capacity of RBB dye using raw RDP. The adsorption removal achieved very important $100 \%$ during 50 minutes with $115.4 \mathrm{mg} / \mathrm{g}$ as adsorption capacity. 


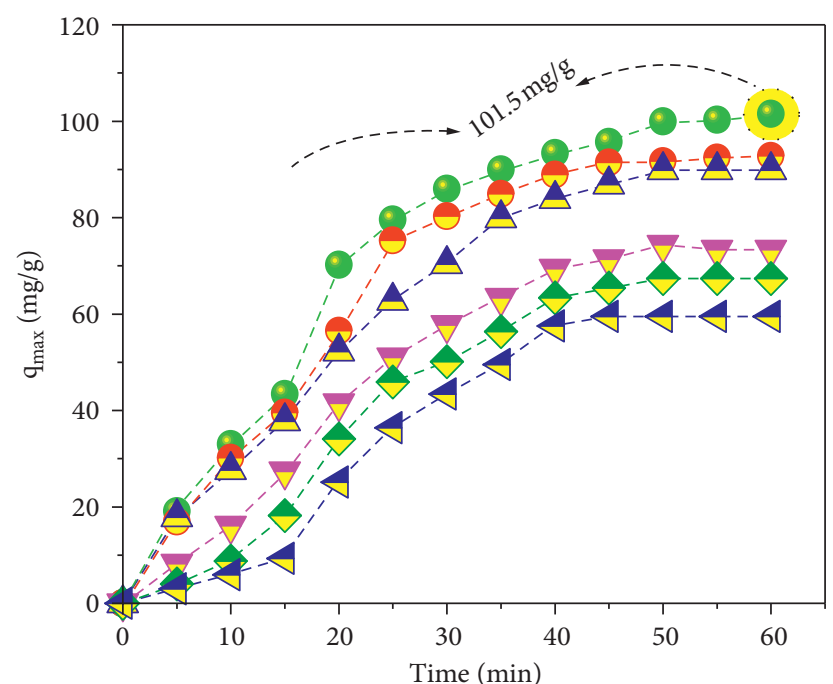

$60 \mathrm{mg} / \mathrm{L}$

$50 \mathrm{mg} / \mathrm{L}$

$40 \mathrm{mg} / \mathrm{L}$ $-\nabla 30 \mathrm{mg} / \mathrm{L}$

$>20 \mathrm{mg} / \mathrm{L}$

(a)

$10 \mathrm{mg} / \mathrm{L}$

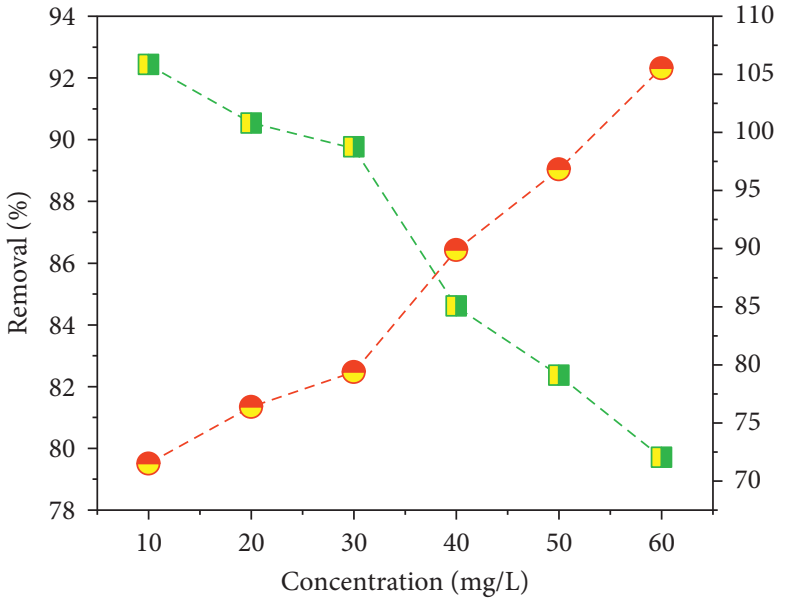

(1. Removal

- Adsorption capacity

FIGURE 7: Initial RBB concentration effect on the adsorption process (a) and the optimal RBB concentration during the adsorption phenomenon (b)

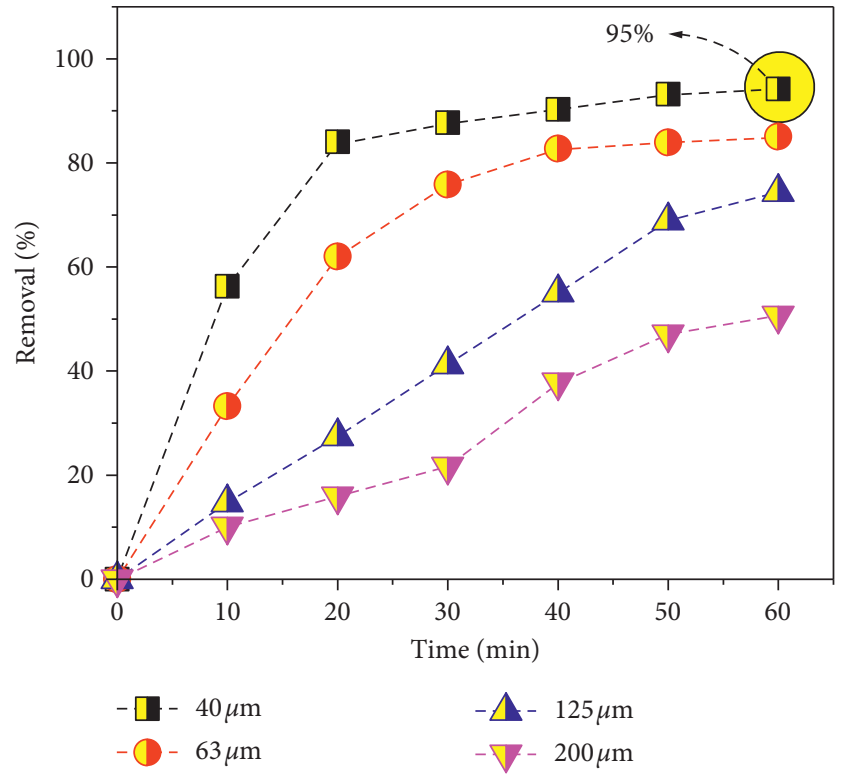

Figure 8: RBB removal at different particle sizes of RDP.

3.3. Isotherms Adsorption. For the study of adsorption isotherms, the Langmuir and Freundlich models were examined and applied to describe the adsorption process of our experimental results (Figure 11(a)). The Langmuir isotherm is one of the models which describes a monolayer adsorption. It assumes a homogeneous adsorption surface with binding sites having equal energies. The linear form of the Langmuir isotherm can be expressed as follows [65]:

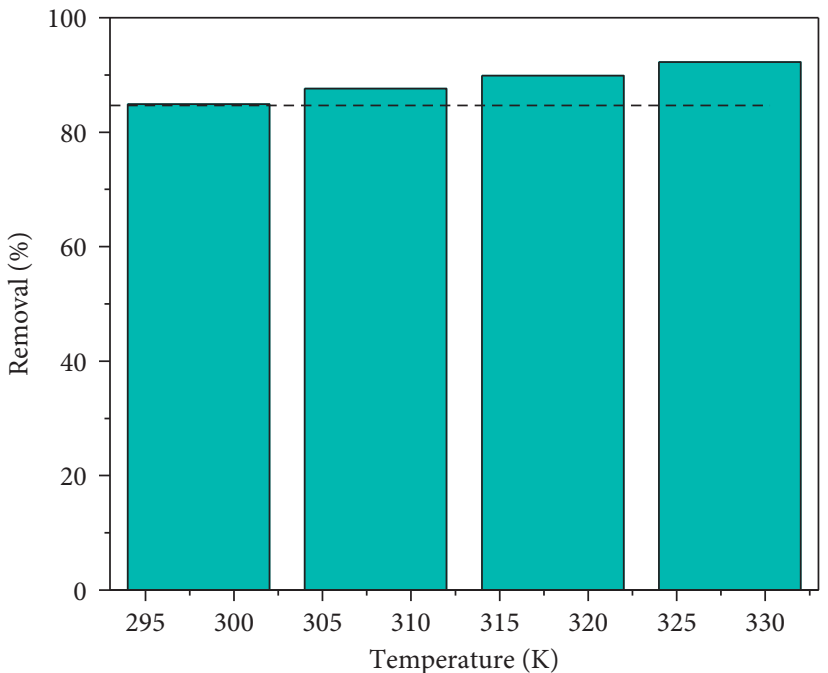

FIgURE 9: Effect of temperature on the RBB adsorption.

$$
\frac{1}{q e}=\frac{1}{q_{\max }}+\frac{1}{\left(K_{L} \times q_{\max }\right)} \times \frac{1}{C_{e}},
$$

where $K_{L}(\mathrm{~L} / \mathrm{mg})$ is the Langmuir constant, $Q_{\max }(\mathrm{mg} / \mathrm{g})$ represents the maximum adsorption capacity under experimental conditions, and $Q_{\max }$ and $K_{L}$ are determined from the plot of $C_{e} / q e$ as a function of $C_{e}$.

From the correlation factor values shown in Table 1, we conclude that the adsorption of RBB by the RDP is well represented by the Langmuir model, with a maximum adsorption capacity of $107.52 \mathrm{mg} / \mathrm{g}$, that is to say the mechanism applied corresponds to a monolayer adsorption which 


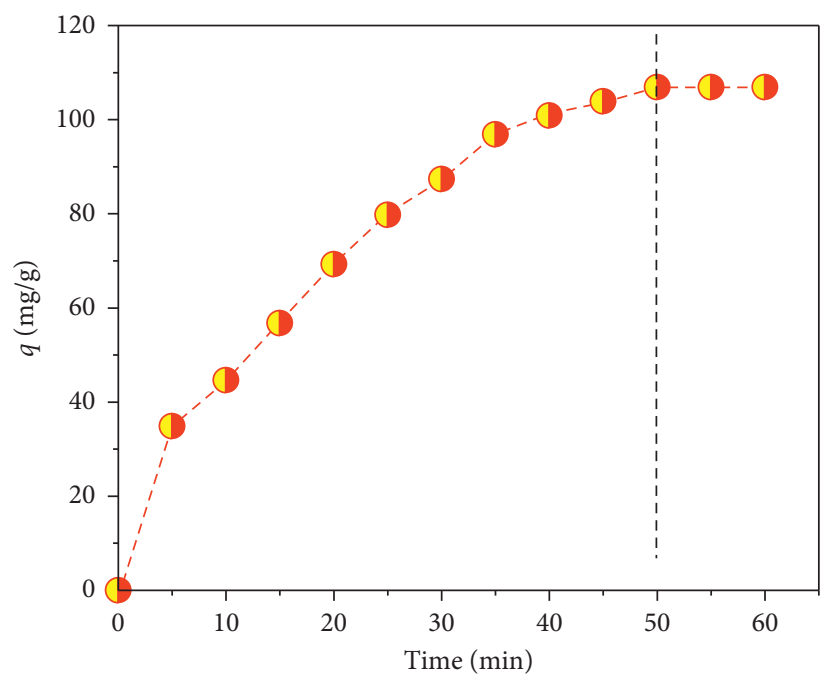

FIGURE 10: Variation in adsorption capacity of RBB at optimum conditions.

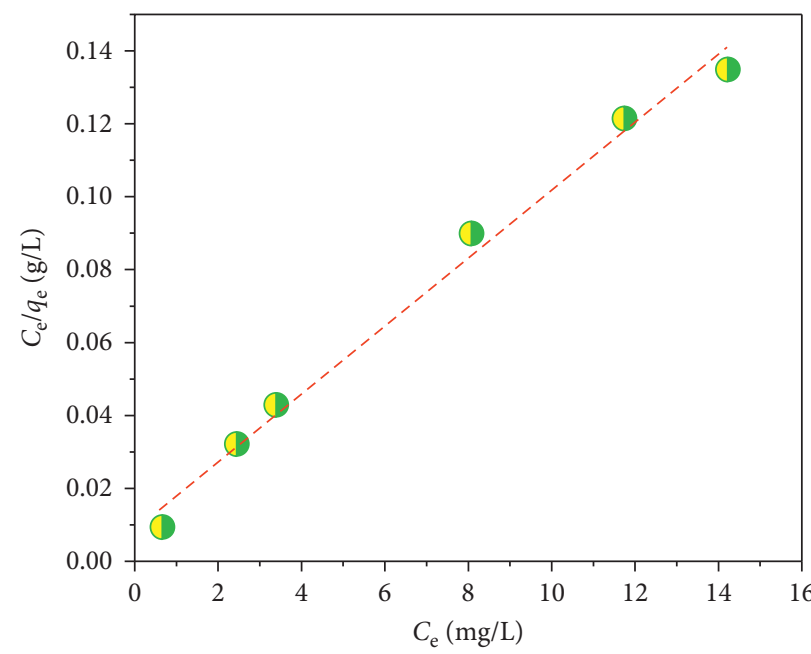

(a)

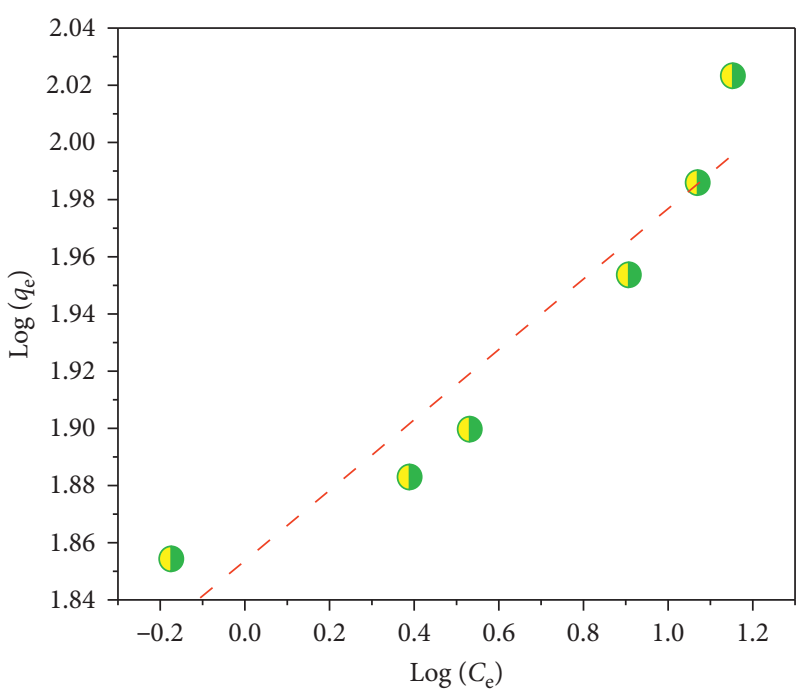

(b)

FIGURE 11: Langmuir isotherm plot (a); Freundlich isotherm plot (b).

TABLE 1: Adsorption isotherm constants of RBB adsorption onto the RDP.

\begin{tabular}{lccccc}
\hline \multicolumn{2}{l}{ Freundlich isotherm } & \multicolumn{3}{c}{ Langmuir isotherm } \\
\hline $1 / n$ & $K_{F}$ & $R^{2}$ & $Q_{\max }$ & $K_{L}$ & $R^{2}$ \\
0.58 & 23.92 & 0.890 & 107.52 & 1.09 & 0.991 \\
\hline
\end{tabular}

involves identical, independent, and limited adsorption sites [66].

During the study of the Freundlich isotherm (Figure 11(b)), the logarithmic equation used is as follows [65]:

$$
\log q_{e}=\log K_{F}+\frac{1}{n} \log C_{e}
$$

By carrying $\log \left(q_{e}\right)$ as a function of $C_{e}$, we obtain a line of slope $1 / n$ and of ordinate at the origin $\log \left(K_{F}\right)$, which makes it possible to determine the constant $K_{F}$ and the heterogeneity factor $(n)$.

The Dubinin-Radushkevich model (Figure 12) does not assume a homogeneous surface or constant adsorption potential, like the Langmuir model. His theory of filling the volume of micropores is based on the fact that the adsorption potential is variable and that the free enthalpy of adsorption is related to the degree of filling of the pores $[67,68]$. The Dubinin-Radushkevich isotherm is given by the following equation [65]:

$$
\ln q_{e}=\ln q_{m \mathrm{DR}}-K_{\mathrm{DR}} \varepsilon^{2},
$$


TABLE 2: D-R isotherm constants.

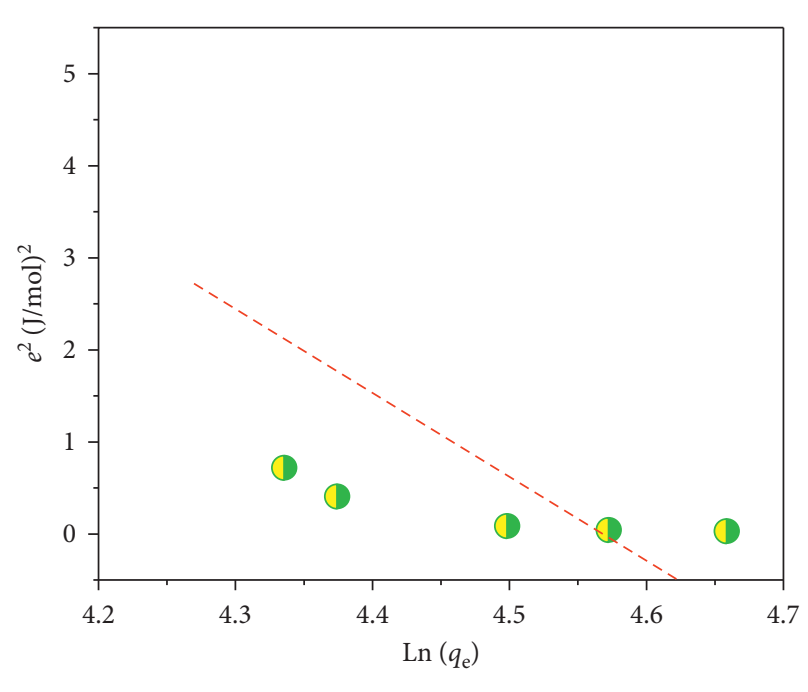

Dubinin-Radushkevich

FIGURE 12: D-R isotherm plot.

where $q_{m \mathrm{DR}}$ is the RDP adsorption capacity at equilibrium $(\mathrm{mg} / \mathrm{g}), K_{\mathrm{DR}}$ is the Dubinin-Radushkevich constant $\left(\mathrm{mol}^{2} /\right.$ $\left.\mathrm{kJ}^{2}\right)$, and $\varepsilon$ is the Polanyi potential $(\mathrm{J} / \mathrm{mol})$.

According to the values of $R^{2}$ (Table 2), the RDP is well represented by this model so it can be said that the adsorbent support has an average energy of adsorption less than $8 \mathrm{~kJ} / \mathrm{mol}$, which indicates that physisorption is the majority.

3.4. Kinetic Models. The kinetics of the pseudo-first-order model and the pseudo-second-order defined, respectively, by the following equations:

$$
\begin{gathered}
\log \left(q_{e}-q_{t}\right)=\log q_{e}-\frac{k 1}{2.303} t, \\
\frac{t}{q}=\frac{1}{k_{2} q_{e}^{2}}+\frac{t}{q} .
\end{gathered}
$$

If the Lagergren relation is verified, by carrying Ln $\left(q_{e}-q_{t}\right)$ as a function of time (Figure 13(a)), we must obtain a line of slope $k_{1}$. In addition, plotting $t / q_{t}$ as a function of time (Figure 13(b)), we must obtain a line with slope $1 / q_{e}$ and ordinate at the origin equal to $1 / k_{2} q_{e}^{2}$.

It is clearly observed that the equation of the pseudofirst-order model is not linear with a correlation coefficient $R^{2}$ very lower (Table 3 ) so that the experimental absorption capacity is very far to that calculated by this model. So, we can deduce that the kinetic of adsorption does not follow the pseudo-first-order model [69] (Figure 13(a)). However, it can be seen from the results obtained (Figure 13(b) and Table 4), and we note that the variation in $t / q_{t}$ as a function of time is very linear, and the regression coefficient $R^{2}$ is satisfactory. Therefore, we can conclude that the kinetics adsorption of RBB using RDP obeyed the pseudo-secondorder model [70].

\begin{tabular}{lccc}
\hline $\mathrm{D}-\mathrm{R}$ isotherm & & & \\
\hline$E(\mathrm{~kJ} / \mathrm{mol})$ & $q_{m}(\mathrm{mg} / \mathrm{g})$ & $K_{\mathrm{DR}}$ & $R^{2}$ \\
1.54 & 90.21 & 0.51 & 0.472 \\
\hline
\end{tabular}

3.5. Adsorption Thermodynamic Studies. The information about the adsorption thermodynamics is very crucial to provide a better understanding of the adsorption process (Figure 14). Therefore, the Van't Hoff equations were used to determine the thermodynamic parameters mainly Gibbsfree energy change $\left(\Delta G^{\circ}\right)$, enthalpy change $\left(\Delta H^{\circ}\right)$, and entropy change $\left(\Delta S^{\circ}\right)$ of the adsorption process from the experimental data and following equations:

$$
\begin{array}{r}
\Delta G^{\circ}=-\operatorname{RTLn}_{L^{\circ}}{ }^{\circ} \\
\operatorname{Ln} K_{L}{ }^{\circ}=\left(\frac{\Delta S^{\circ}}{\mathrm{R}}\right)-\left(\frac{\Delta \mathrm{H}^{\circ}}{\mathrm{RT}}\right), \\
\Delta G^{\circ}=\Delta H^{\circ}-T \Delta S^{\circ},
\end{array}
$$

where $\Delta G^{\circ}$ is the standard free energy, $\mathrm{kJ} / \mathrm{mol} ; T$ is the absolute solution temperature, $\mathrm{K} ; \Delta H^{\circ}$ is the standard enthalpy, $\mathrm{kJ} / \mathrm{mol} ; R$ is the universal gas constant, $8.314 \mathrm{~J} / \mathrm{mol} . \mathrm{K}$; and $\Delta S^{\circ}$ is the standard entropy, $\mathrm{J} / \mathrm{K}$.

As shown in Table 5, the negative values of $\Delta \mathrm{G}^{\circ}$ at 298 , 308,318 , and 328 indicate that adsorption spontaneity is favored at these temperatures. A similar trend has been observed at 308,318 , and $328 \mathrm{~K}$ for the adsorption of RBB onto RDP. The positive $\Delta H$ value $47.62 \mathrm{~kJ} / \mathrm{mol}$ confirmed the endothermic nature of RBB adsorption, while the slightly $\Delta S$ value $0.048 \mathrm{~kJ} / \mathrm{mol} \cdot \mathrm{K}$ reveals an increase in the randomness at the RBB-RDP-solution interface during the adsorption process [71].

\section{Proposed Mechanisms of RBB Adsorption}

It was shown that $\mathrm{RBB}$ was adequately adsorbed for $\mathrm{pH}$ between 2 and 9, which may be due to the formation of surface hydrogen bonds between the hydroxyl groups on the raw RDP surface and the nitrogen atoms of RBB, as suggested in Figure 15. The large number and array of carboxylic and hydroxyl groups on the RDP surface implied existence of many types of RDP-RBB interaction. Moreover, in the desorption studies, the adsorption of RBB onto the raw $\mathrm{RDP}$ resulted in formation of an instable chemical bond between the raw RDP surface and the RBB molecules, which favored the dye molecules from being eluted from the raw RDP surface. However, higher amount of RBB molecules was eluted $(\sim 60)$. The electrostatic attraction between RBB and RDP enhances the adsorption phenomenon, which leads adsorbent more suitable to adsorb the dye [72].

\section{Effect of Ionic Strength}

The ionic strength caused by the presence of salts in solution is one of the factors that controls both electrostatic and nonelectrostatic interactions between the adsorbate and the adsorbent surface [73]. In this study, $\mathrm{NaCl}$ and $\mathrm{BaCl}_{2}(0.1$ to 
TABLE 3: Kinetic constants of the pseudo-first-order model.

\begin{tabular}{|c|c|c|c|c|}
\hline Initial concentration $(\mathrm{mg} / \mathrm{L})$ & Experimental $q_{e}(\mathrm{mg} / \mathrm{g})$ & $k_{1}\left(\min ^{-1}\right)$ & Theoretical $q_{e}(\mathrm{mg} / \mathrm{g})$ & $R^{2}$ \\
\hline 10 & 71.5 & 0.069 & 91.02 & 0.970 \\
\hline 20 & 76.37 & 0.110 & 101.5 & 0.972 \\
\hline 30 & 79.37 & 0.152 & 184.93 & 0.691 \\
\hline 40 & 89.87 & 0.163 & 192.4 & 0.718 \\
\hline 50 & 96.8 & 0.013 & 69.57 & 0.740 \\
\hline 60 & 105.5 & 0.082 & 125.3 & 0.911 \\
\hline
\end{tabular}

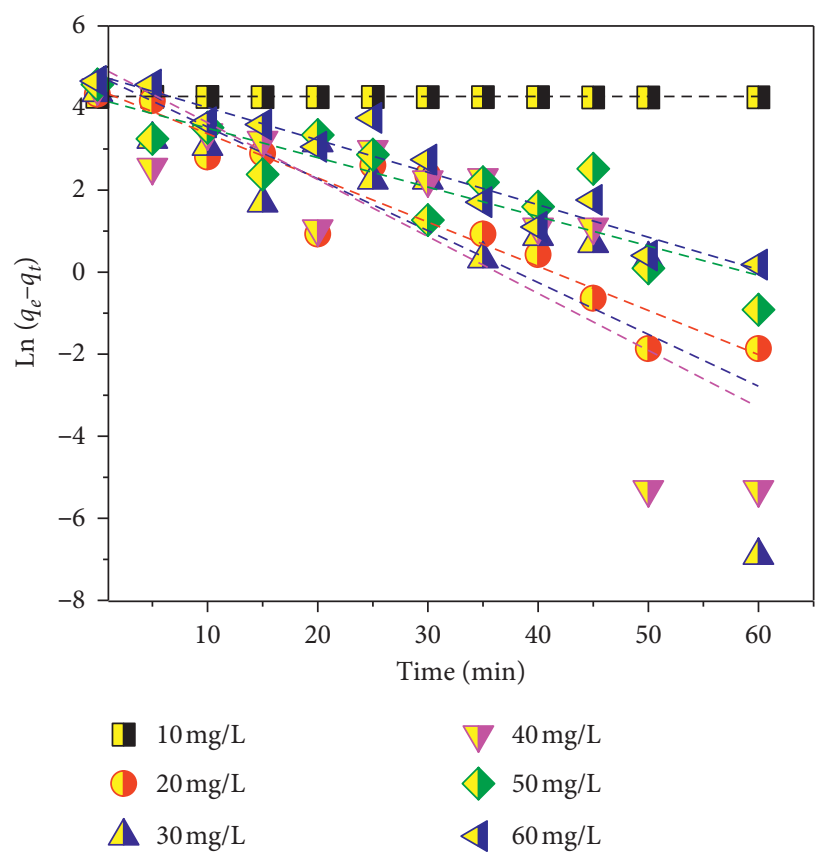

(a)

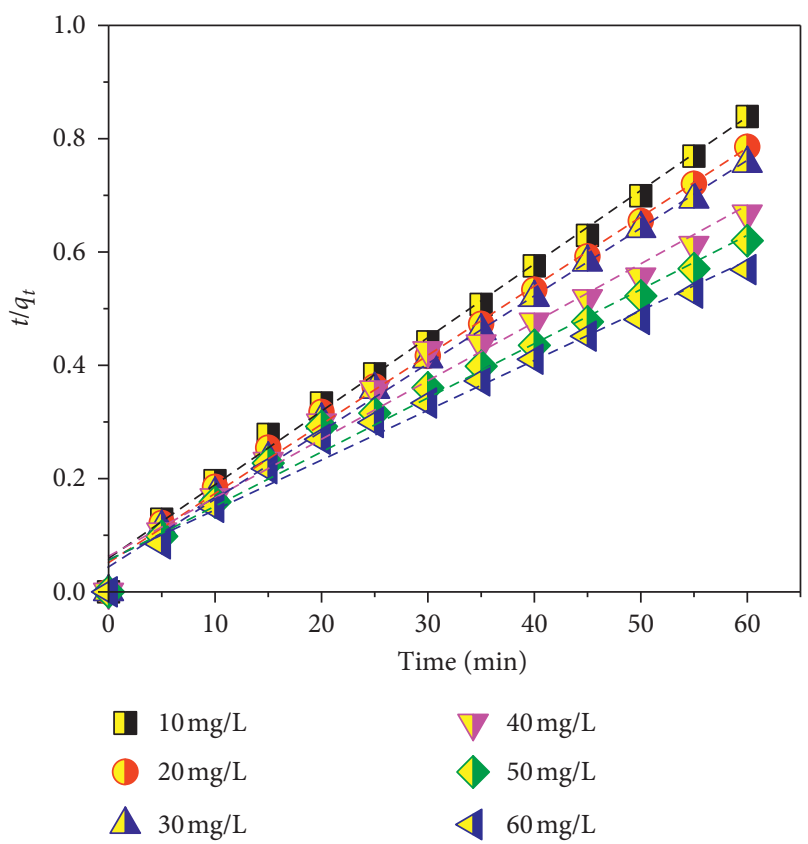

(b)

FIgURE 13: Pseudo-first-order kinetic of the RBB adsorption on RDP (a) and pseudo-second-order kinetic of the RBB adsorption on RDP (b).

TABLE 4: Kinetic constants of the second-first-order model.

\begin{tabular}{lcccc}
\hline $\begin{array}{l}\text { Initial } \\
\text { concentration } \\
(\mathrm{mg} / \mathrm{L})\end{array}$ & $\begin{array}{c}\text { Experimental } \\
q_{e}(\mathrm{mg} / \mathrm{g})\end{array}$ & $\begin{array}{c}K_{2}(\mathrm{~g} / \\
\mathrm{mol} \cdot \mathrm{min})\end{array}$ & $\begin{array}{c}\text { Theoretical } \\
q_{e}(\mathrm{mg} / \mathrm{g})\end{array}$ & $R^{2}$ \\
\hline 10 & 71.5 & $3.13 .10^{-3}$ & 76.33 & 0.990 \\
20 & 76.37 & $3.61 .10^{-3}$ & 81.96 & 0.994 \\
30 & 79.37 & $3.23 .10^{-3}$ & 83.3 & 0.995 \\
40 & 89.87 & $1.66 .10^{-3}$ & 97.08 & 0.978 \\
50 & 96.8 & $1.53 .10^{-3}$ & 105.26 & 0.982 \\
60 & 105.5 & $1.37 .10^{-3}$ & 113.63 & 0.980 \\
\hline
\end{tabular}

$0.5 \mathrm{M}$ ) are used to increase the ionic strength of the RBB solution. Figure 16 illustrates that the concentrations of $0.5 \mathrm{M} \mathrm{NaCl}$ and $0.5 \mathrm{M} \mathrm{BaCl}_{2}$ are sufficient to achieve these maximums of adsorption, for example, an initial concentration of RBB $40 \mathrm{mg} / \mathrm{L}$. As it can be observed in Figure 16, an increase in the adsorption capacity is more for $\mathrm{BaCl}_{2}$ than $\mathrm{NaCl}$, compared with the adsorption of $\mathrm{RBB}$ without salts. This result could be justified by the fact that $\mathrm{BaCl}_{2}$ is a porter of more positive charges than $\mathrm{NaCl}$ on the surface of raw RDP [56]. Overall, the improvement of removal of RBB with

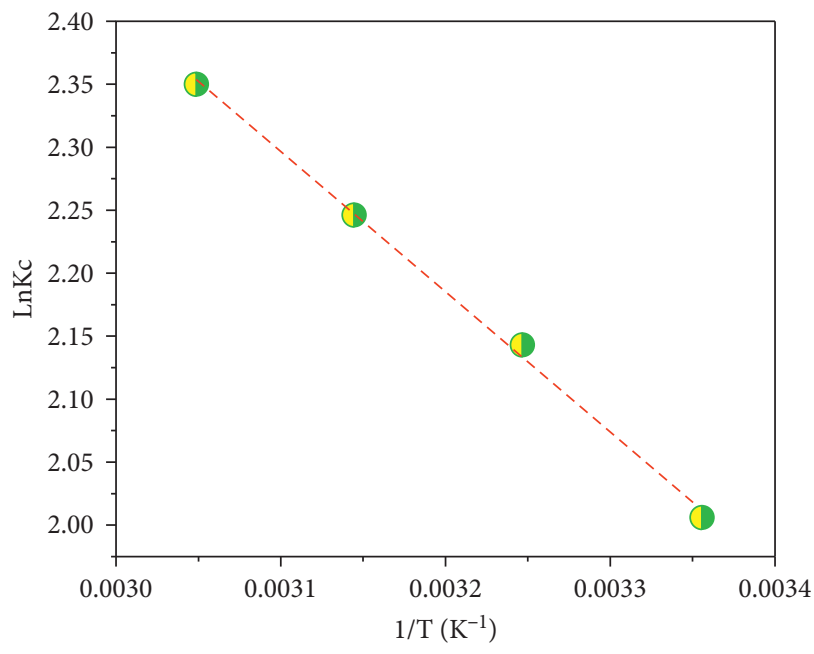

Figure 14: Plot of $\operatorname{Ln} K_{C}$ vs $1 / T$.

increasing ionic strength can be explained by the increase in the positive charges on the surface of the adsorbent. Thus, it increases the electrostatic interaction between the RBB and 


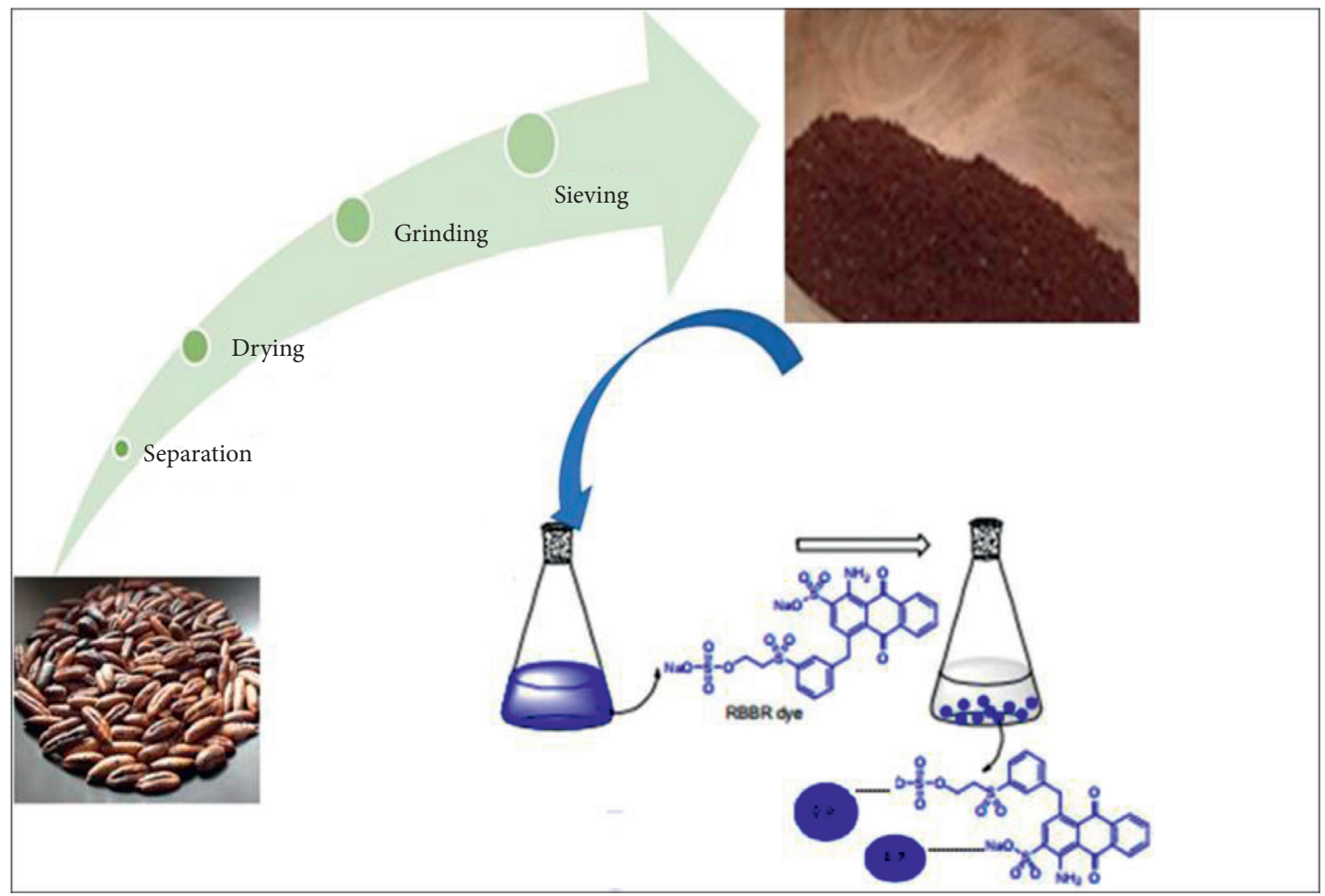

FIGURE 15: Illustration of RBB dye interaction with RDP adsorbent.

TABLE 5: Thermodynamic parameters of RBB adsorption onto the RDP.

\begin{tabular}{cccc}
\hline$(\mathrm{K})$ & $\Delta H^{\circ}\left(\mathrm{kJ} \cdot \mathrm{mol}^{-1}\right)$ & $\Delta S^{\circ}\left(\mathrm{kJ} \cdot \mathrm{mol}^{-1} \cdot \mathrm{K}^{-1}\right)$ & $\Delta G^{\circ}\left(\mathrm{kJ} \cdot \mathrm{mol}^{-1}\right)$ \\
\hline 298 & & & -5.007 \\
308 & & & -5.552 \\
318 & 9.232 & 0.048 & -6.032 \\
328 & & & -6.512 \\
\hline
\end{tabular}

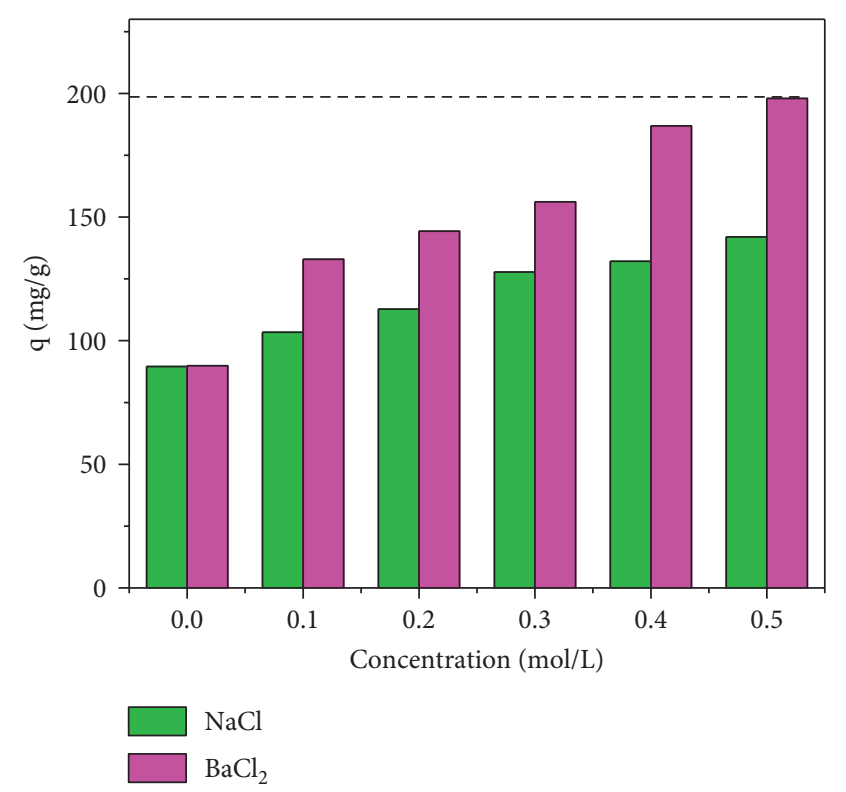

Figure 16: Effect of ionic strength on the removal of RBB onto RDP.
RDP surfaces. Similar observation was found [34] during the removal of RBB by cross-linked chitosan resins, using only $\mathrm{NaCl}$.

\section{Desorption, Cycles of Regeneration, and Interest of Using Raw RDP}

This study aims at evaluating the adsorption rate of RBB and his desorption or the regeneration rate of the biomaterial adsorbent. This contribution gives an idea about the overall cost of the treatment process. All experiments were carried out after saturation of RDP at $1.5 \mathrm{~g} / \mathrm{L}$, with an initial solution RBB of $40 \mathrm{mg} / \mathrm{L}$. Desorption experiments were conducted with different eluents, such as distilled water, $\mathrm{NaOH}, \mathrm{HCl}$, ethanol, and acetone. Figure 17 shows that acetone has given significant results of desorption. According to the obtained results, no interesting desorption is observed in the acidic medium. However, in the presence of $\mathrm{NaOH}$, the desorption of $\mathrm{RBB}$ is approximately $37 \%$ successively. This behavior is related to the anionic nature of $\mathrm{RBB}$, and to the ion exchange, and the functional groups content on the surface of the adsorbent. The adsorption-desorption cycles with $1: 1$ acetone water (v/v) were used as optimum solvent during the regeneration experiment. Figure 18 shows that the regeneration of RDP is possible, but not satisfactorily, due to the loss of adsorbent material performance [74]. This phenomenon is commonly explained by the loss of active sites on the surface of the adsorbent [75]. 


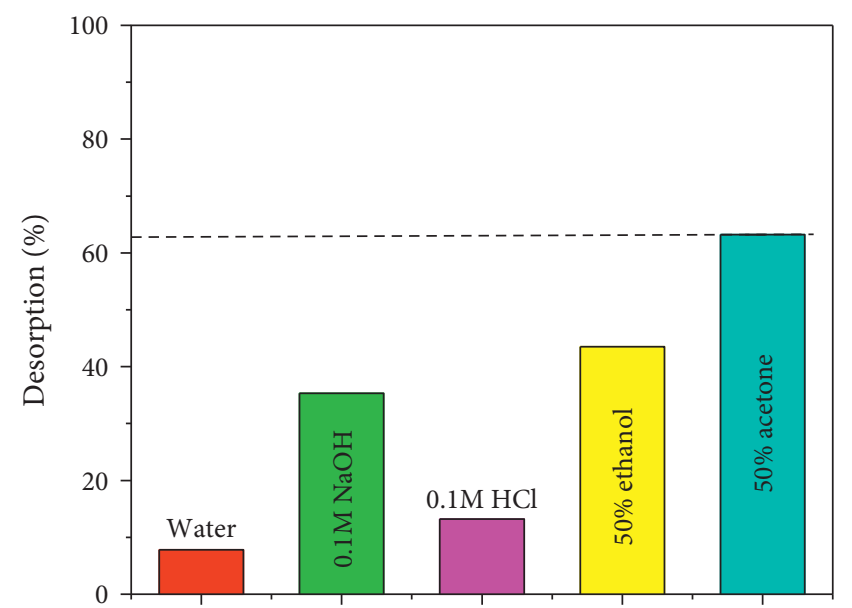

Figure 17: Desorption of RBB using different eluents.

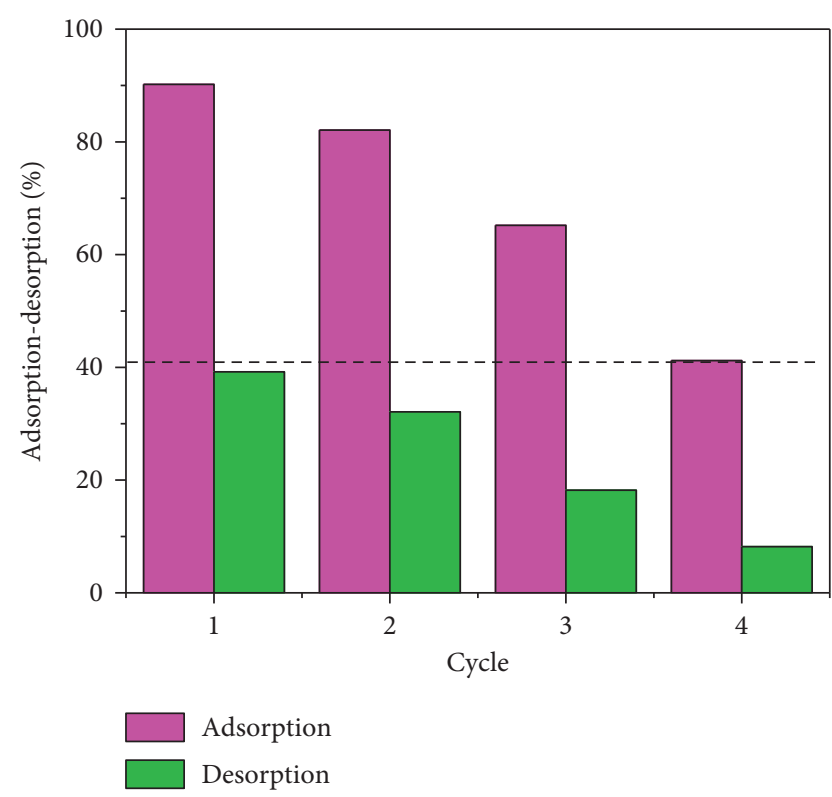

Figure 18: Desorption of RBB using 50\% acetone after 4 cycles.

\section{Comparison of the Treatment Efficiency with Literature Studies}

The efficiency of the adsorption capacity towards different dyes, according to the literature studies, is presented in Table 6 [76-78] in which we have included the results of the present work and the conditions for establishing comparisons. As it can be seen in Table 6, the different biomaterials are used for the adsorption of RBB. The present work shows an important adsorption capacity, during a fast contact time of $50 \mathrm{~min}$. Consequently, Moroccan RDP could be a promising bioadsorbent for the elimination of dyes in aqueous solutions.
TABLE 6: Comparison of the treatment efficiency with literature studies.

\begin{tabular}{lcccc}
\hline Adsorbent & Dyes & $\begin{array}{c}\text { Adsorption } \\
\text { capacities (mg/g) }\end{array}$ & $\begin{array}{c}\text { Contact } \\
\text { time (min) }\end{array}$ & Reference \\
\hline $\begin{array}{l}\text { RDP } \\
\begin{array}{l}\text { Pineapple leaf } \\
\text { powder }\end{array}\end{array}$ & RBB & 105 & 50 & This work \\
$\begin{array}{l}\text { Salvinia } \\
\text { natans }\end{array}$ & RBB & 6.62 & 900 & {$[76]$} \\
Orange peel & RBB & 9.7 & 800 & {$[77]$} \\
\hline
\end{tabular}

\section{Conclusion}

RDP compared to various bioadsorbents has the potential in removing $\mathrm{RBB}$ from aqueous solutions. The experimental results have shown that the absorption maximum is obtained at initial $\mathrm{RBB}$ concentration $40 \mathrm{mg} / \mathrm{L}, \mathrm{pH} 2$, equilibrium contact time $50 \mathrm{~min}$, temperature $328 \mathrm{~K}$, particle diameter $40 \mu \mathrm{m}$, and RDP mass $1.5 \mathrm{~g} / \mathrm{L}$. Increasing the ionic strength of the dye solution with $0.5 \mathrm{M} \mathrm{BaCl}_{2}$ enhances the adsorption capacity till $198 \mathrm{mg} / \mathrm{g}$. Experimental data were adequately interpreted by Langmuir isotherm and pseudosecond-order kinetics. Therefore, RDP has proved effectiveness to remove $\mathrm{RBB}$ from solution. In addition to the advantage of its availability in large quantity in Mauritania, it presents an eco-friendly alternative to traditional processes of textile wastewater treatment even though the test of adsorption-desorption cycles demonstrates that the bioadsorbent cannot be used several times, and it is still a costeffective bioadsorbent, taking into account the high adsorption yield reached. Moreover, exploring the feasibility of using the RDP before and after thermic treatment could be an important perspective for future work.

\section{Data Availability}

All data underlying the findings of this study are fully available without restriction.

\section{Conflicts of Interest}

The authors declare that they have no conflicts of interest.

\section{Acknowledgments}

The authors thank the general services (SEM, XRD, and Infrared) of the innovation center, University of $\mathrm{Fez}$ (Morocco).

\section{References}

[1] F. Mejbar, Y. Miyah, A. El Badraoui et al., "Studies of the adsorption kinetics process for removal of methylene blue dye by residue of grenadine bark extraction," Moroccan Journal of Chemistry, vol. 6, pp. 436-443, 2019.

[2] N. Loubna, Y. Miyah, O. Assila, A. El Badraoui, B. El Khazzan, and F. Zerrouq, "Kinetic and thermodynamicstudy of the adsorption of twodyes: brilliant green and eriochrome black $\mathrm{T}$ using a natural adsorbent "sugarcane bagasse"” Moroccan Journal of Chemistry.vol. 7, pp. 715-726, 2019. 
[3] M. A. Al-ghouti, J. Li, Y. Salamh, N. Al-laqtah, G. Walker, and M. N. M. Ahmad, "Adsorption mechanisms of removing heavy metals and dyes from aqueous solution using date pits solid adsorbent," Journal of Hazardous Materials, vol. 176, no. 1-3, pp. 510-520, 2010.

[4] K. M. Kifuani, A. Kifuani Kia Mayeko, P. Noki Vesituluta et al., "Adsorption d'un colorant basique, Bleu de Méthylène, en solution aqueuse, sur un bioadsorbant issu de déchets agricoles de," International Journal of Biological and Chemical Sciences, vol. 12, 2018.

[5] F. Alakhras, E. Alhajri, R. Haounati, H. Ouachtak, A. A. Addi, and T. A. Saleh, "A comparative study of photocatalytic degradation of rhodamine B using natural-based zeolite composites," Surfaces and Interfaces, vol. 20, 2020.

[6] Z. Bencheqroun, Z. Chaouki, M. Hadri et al., "Removal of textile dyes from aqueous solutions using low cost Moroccan clay," IOP Conference Series: Earth and Environmental Science, vol. 161, 2018.

[7] A. A. Basaleh, M. H. Al-Malack, and T. A. Saleh, "Methylene Blue removal using polyamide-vermiculite nanocomposites: kinetics, equilibrium and thermodynamic study," Journal of Environmental Chemical Engineering, vol. 7, no. 3, p. 103107, 2019.

[8] M. Alipour, M. Vosoughi, S. A. Mokhtari et al., "Optimising the basic violet 16 adsorption from aqueous solutions by magnetic graphene oxide using the response surface model based on the Box-Behnken design," International Journal of Environmental Analytical Chemistry, pp. 1-20, 2019.

[9] R. Ahmad and R. Kumar, "Adsorptive removal of Congo red dye from aqueous solution using bael shell carbon," Applied Surface Science, vol. 257, no. 5, pp. 1628-1633, 2010.

[10] L. Bulgariu, L. B. Escudero, O. S. Bello et al., "The utilization of leaf-based adsorbents for dyes removal: a review," Journal of Molecular Liquids, vol. 276, pp. 728-747, 2019.

[11] H. N. Bhatti, A. Jabeen, M. Iqbal, S. Noreen, and Z. Naseem, "Adsorptive behavior of rice bran-based composites for malachite green dye: isotherm, kinetic and thermodynamic studies," Journal of Molecular Liquids, vol. 237, pp. 322-333, 2017.

[12] M. Ahmad, G. Abbas, R. Haider et al., "Kinetics and equilibrium studies of eriobotrya japonica: a novel adsorbent preparation for dyes sequestration," Zeitschrift für Physikalische Chemie, vol. 233, no. 10, pp. 1-16, 2018.

[13] S. Ledakowicz, M. Solecka, and R. Zylla, "Biodegradation, decolourisation and detoxification of textile wastewater enhanced by advanced oxidation processes," Journal of Biotechnology, vol. 89, no. 2-3, pp. 175-184, 2001.

[14] F. Zhou, Y. Cheng, L. Gan, Z. Chen, M. Megharaj, and R. Naidu, "Burkholderia vietnamiensis $\mathrm{C} 09 \mathrm{~V}$ as the functional biomaterial used to remove crystal violet and $\mathrm{Cu}(\mathrm{II})$, , Ecotoxicology and Environmental Safety, vol. 105, pp. 1-6, 2014.

[15] K. Tanji, J. A. Navio, A. Chaqroune et al., "Fast photodegradation of rhodamine $\mathrm{B}$ and caffeine using ZnO-hydroxyapatite composites under UV-light illumination," Catalysis Today, 2020.

[16] M. Zouhier, K. Tanji, J. A. Navio, M. C. Hidalgo, C. JaramilloPáez, and A. Kherbeche, "Preparation of $\mathrm{ZnFe}_{2} \mathrm{O}_{4} / \mathrm{ZnO}$ composite: effect of operational parameters for photocatalytic degradation of dyes under UV and visible illumination," Journal of Photochemistry and Photobiology A: Chemistry, vol. 390, 2020.

[17] K. Tanji, J. A. Navio, A. N. Martín-Gómez et al., "Role of $\mathrm{Fe}(\mathrm{III})$ in aqueous solution or deposited on $\mathrm{ZnO}$ surface in the photoassisted degradation of rhodamine B and caffeine," Chemosphere, vol. 241, 2019.

[18] K. Tanji, J. A. Navio, J. Naja et al., "Extraordinary visible photocatalytic activity of a Co $0.2 \mathrm{Zn} 0.8 \mathrm{O}$ system studied in the Remazol BB oxidation," Journal of Photochemistry and Photobiology A: Chemistry, vol. 382, p. 111877, 2019.

[19] N. Javid, Z. Honarmandrad, and M. Malakootian, "Ciprofloxacin removal from aqueous solutions by ozonation with calcium peroxide," Desalination and Water Treatment, vol. 174, pp. 178-185, 2020.

[20] Z. Honarmandrad, N. Javid, and M. Malakootian, "Efficiency of ozonation process with calcium peroxide in removing heavy metals $(\mathrm{Pb}, \mathrm{Cu}, \mathrm{Zn}, \mathrm{Ni}, \mathrm{Cd})$ from aqueous solutions," SN Applied Sciences, vol. 2, no. 4, pp. 1-7, 2020.

[21] A. Ait hssi, E. Amaterz, N. labchir et al., "Electrodeposited $\mathrm{ZnO}$ nanorods as efficient photoanodes for the degradation of rhodamine B," Physica Status Solidi, vol. 217, no. 17, 2020.

[22] E. Amaterz, A. Tara, A. Bouddouch et al., "Hierarchical flower-like SrHPO4 electrodes for the photoelectrochemical degradation of Rhodamine B," Journal of Applied Electrochemistry, vol. 50, no. 5, pp. 569-581, 2020.

[23] K. B. Tan, M. Vakili, B. A. Horri, P. E. Poh, A. Z. Abdullah, and B. Salamatinia, "Adsorption of dyes by nanomaterials: recent developments and adsorption mechanisms," Separation and Purification Technology, vol. 150, pp. 229-242, 2015.

[24] M. M. Al-a'qarbeh, M. W. Shammout, and A. M. Awwad, "Nano platelets kaolinite for the adsorption of toxic metal ions in the environment," International Journal of Chemistry, vol. $6,2020$.

[25] A. M. Alasadi, F. I. Khaili, and A. M. Awwad, "Adsorption of $\mathrm{Cu}$ ( II ), Ni ( II ) and Zn ( II ) ions by nano kaolinite: thermodynamics and kinetics studies," International Journal of Chemistry, vol. 5, pp. 258-268, 2019.

[26] A. Farsi, N. Javid, and M. Malakootian, "Investigation of adsorption efficiency of $\mathrm{Cu} 2+$ and $\mathrm{Zn} 2+$ by red soil and activated bentonite from acid copper mine drainage," Desalination and Water Treatment, vol. 144, pp. 172-184, 2019.

[27] M. Mahmoodi Meimand, N. Javid, and M. Malakootian, "Adsorption of sulfur dioxide on clinoptilolite/nano iron oxide and natural clinoptilolite," Health Scope, vol. 8, Article ID e69158, 2019.

[28] A. Hamzezadeh, Y. Rashtbari, S. Afshin, M. Morovati, and M. Vosoughi, "Application of low-cost material for adsorption of dye from aqueous solution," International Journal of Environmental Analytical Chemistry, pp. 1-16, 2020.

[29] M. Fazal-ur-rehman, "Current scenario and future prospects of activated carbon preparation from agro- industrial wastes : a review," International Journal of Chemistry, vol. 4, pp. 109-119, 2018.

[30] A. M. Alkherraz, A. K. Ali, and K. M. Elsherif, "Removal of Pb (II), Zn (II), Cu (II) and Cd (II) from aqueous solutions by adsorption onto olive branches activated carbon: equilibrium and thermodynamic studies," International Journal of Chemistry, vol. 6, pp. 11-20, 2020.

[31] F. Sakr, A. Sennaoui, M. Elouardi, M. Tamimi, and A. Assabbane, "Etude de l'adsorption du Bleu de Méthylène sur un biomatériau à base deCactus (Adsorption study of Methylene Blue on biomaterial using cactus)," Journal of Materials and Environmental Science, vol. 6, pp. 397-406, 2015.

[32] Y. Miyah, M. Idrissi, and F. Zerrouq, "Etude et Modélisation de la Cinétique d'Adsorption du Bleu de Méthylène sur les Adsorbants Argileux (Pyrophillite, Calcite) Study and Modeling of the Kinetics Methylene blue Adsorption on the Clay 
Adsorbents (Pyrophillite, Calcite)," Journal of Materials and Environmental Science, vol. 6, pp. 699-712, 2015.

[33] K. K. H. Choy, G. McKay, and J. F. Porter, "Sorption of acid dyes from effluents using activated carbon," Resources, Conservation and Recycling, vol. 27, no. 1-2, pp. 57-71, 1999.

[34] L.-X. Zeng, Y.-F. Chen, Q.-Y. Zhang, Y. Kang, and J.-W. Luo, "Adsorption of Congo red by cross-linked chitosan resins," Desalination and Water Treatment, vol. 52, no. 40-42, pp. 7733-7742, 2014.

[35] Z. Zhang, W. Wang, Y. Kang, L. Zong, and A. Wang, "Tailoring the properties of palygorskite by various organic acids via a one-pot hydrothermal process: a comparative study for removal of toxic dyes," Applied Clay Science, vol. 120, pp. 28-39, 2016.

[36] O. Assila, K. Tanji, M. Zouheir et al., "Adsorption studies on the removal of textile effluent over two natural eco-friendly adsorbents," Journal of Chemistry, vol. 2020, Article ID 6457825, 13 pages, 2020.

[37] R. Haounati, O. Hassan, H. RachidEl et al., "Elaboration and properties of a new SDS/CTAB@Montmorillonite organoclay compositeas a superb adsorbent for the removal of malachite green from aqueous solutions," Separation and Purification Technology, vol. 255, Article ID 117335, 2020.

[38] R.-R. Shan, L.-G. Yan, Y.-M. Yang et al., "Highly efficient removal of three red dyes by adsorption onto $\mathrm{Mg}$-Al-layered double hydroxide," Journal of Industrial and Engineering Chemistry, vol. 21, pp. 561-568, 2015.

[39] S. Chakma and V. S. Moholkar, "Synthesis of bi-metallic oxides nanotubes for fast removal of dye using adsorption and sonocatalysis process," Journal of Industrial and Engineering Chemistry, vol. 37, pp. 84-89, 2016.

[40] H. Ouachtak, S. Akhouairi, R. Haounati et al., "3,4-Dihydroxybenzoic acid removal from water by goethite modified natural sand column fixed-bed: experimental study and mathematical modeling," Desalination and Water Treatment, vol. 194, pp. 439-449, 2020.

[41] A. Dra, A. El Gaidoumi, K. Tanji, A. Chaouni Benabdallah, A. Taleb, and A. Kherbeche, "Characterization and quantification of heavy metals in oued sebou sediments," The Scientific World Journal, vol. 2019, 2019.

[42] A. Dra, K. Tanji, A. Arrahli et al., "Valorization of oued sebou natural sediments (Fez-Morocco area) as adsorbent of methylene blue dye: kinetic and thermodynamic study," The Scientific World Journal, vol. 2020, pp. 1-8, 2020.

[43] M. Arami, N. Y. Limaee, N. M. Mahmoodi, and N. S. Tabrizi, "Removal of dyes from colored textile wastewater by orange peel adsorbent: equilibrium and kinetic studies," Journal of Colloid and Interface Science, vol. 288, no. 2, pp. 371-376, 2005.

[44] M. S. Rahman, S. Kasapis, N. S. Z. Al-Kharusi, I. M. AlMarhubi, and A. J. Khan, "Composition characterisation and thermal transition of date pits powders," Journal of Food Engineering, vol. 80, no. 1, pp. 1-10, 2007.

[45] N. Javid and M. Malakootian, "Removal of bisphenol a from aqueous solutions by modified-carbonized date pits by zno nano-particles," Desalination and Water Treatment, vol. 95, pp. 144-151, 2017.

[46] N. Javid, A. Nasiri, and M. Malakootian, "Removal of nonylphenol from aqueous solutions using carbonized date pits modified with $\mathrm{ZnO}$ nanoparticles," Desalination and Water Treatment, vol. 141, pp. 140-148, 2019.

[47] N. Kannan and M. Meenakshisundaram, "Adsorption of Congo red on various activated carbons," Water, Air, and Soil Pollution, vol. 138, pp. 289-305, 2002.
[48] P. Senthil Kumar, S. Ramalingam, C. Senthamarai, M. Niranjanaa, P. Vijayalakshmi, and S. Sivanesan, "Adsorption of dye from aqueous solution by cashew nut shell: studies on equilibrium isotherm, kinetics and thermodynamics of interactions," Desalination, vol. 261, no. 1-2, pp. 52-60, 2010.

[49] C. Bouchelta, M. S. Medjram, O. Bertrand, and J.-P. Bellat, "Preparation and characterization of activated carbon from date stones by physical activation with steam," Journal of Analytical and Applied Pyrolysis, vol. 82, no. 1, pp. 70-77, 2008.

[50] H. M. Al-Saidi, "The fast recovery of gold(III) ions from aqueous solutions using raw date pits: kinetic, thermodynamic and equilibrium studies," Journal of Saudi Chemical Society, vol. 20, no. 6, pp. 615-624, 2016.

[51] S. M. Yakout and G. Sharaf El-Deen, "Characterization of activated carbon prepared by phosphoric acid activation of olive stones," Arabian Journal of Chemistry, vol. 9, pp. S1155-S1162, 2016.

[52] A.-N. A. El-Hendawy, "Variation in the FTIR spectra of a biomass under impregnation, carbonization and oxidation conditions," Journal of Analytical and Applied Pyrolysis, vol. 75, no. 2, pp. 159-166, 2006.

[53] R. El Haouti, H. Ouachtak, A. El Guerdaoui et al., "Cationic dyes adsorption by Na-Montmorillonite Nano Clay: experimental study combined with a theoretical investigation using DFT-based descriptors and molecular dynamics simulations," Journal of Molecular Liquids, vol. 290, 2019.

[54] A. M. M. Vargas, A. L. Cazetta, M. H. Kunita, T. L. Silva, and V. C. Almeida, "Adsorption of methylene blue on activated carbon produced from flamboyant pods (Delonix regia): study of adsorption isotherms and kinetic models," Chemical Engineering Journal, vol. 168, no. 2, pp. 722-730, 2011.

[55] M. Arulkumar, P. Sathishkumar, and T. Palvannan, "Optimization of Orange $\mathrm{G}$ dye adsorption by activated carbon of Thespesia populnea pods using response surface methodology," Journal of Hazardous Materials, vol. 186, no. 1, pp. 827-834, 2011.

[56] R. Hachani, H. Sabir, N. Sana, K. F. Zohra, and N. M. Nesrine, "Performance study of a low-cost adsorbent-raw date pits-for removal of azo dye in aqueous solution," Water Environment Research, vol. 89, no. 9, pp. 827-839, 2017.

[57] A. Tor and Y. Cengeloglu, "Removal of Congo red from aqueous solution by adsorption onto acid activated red mud," Journal of Hazardous Materials, vol. 138, no. 2, pp. 409-415, 2006.

[58] M. El Marouani, K. Azoulay, I. Bencheikh et al., "Application of raw and roasted date seeds for dyes removal from aqueous solution," Journal of Materials and Environmental Science, vol. 9, pp. 2387-2396, 2018.

[59] A. Saeed, M. Sharif, and M. Iqbal, "Application potential of grapefruit peel as dye sorbent: kinetics, equilibrium and mechanism of crystal violet adsorption," Journal of Hazardous Materials, vol. 179, no. 1-3, pp. 564-572, 2010.

[60] E. Lorenc-Grabowska and G. Gryglewicz, "Adsorption characteristics of Congo red on coal-based mesoporous activated carbon," Dye Pigment, vol. 74, no. 1, pp. 34-40, 2006.

[61] M. Özacar and I. A. Şengil, "Equilibrium data and process design for adsorption of disperse dyes onto Alunite," Environmental Geology, vol. 45, pp. 762-768, 2004.

[62] A. Seidmohammadi, G. Asgari, A. Dargahi et al., "A comparative study for the removal of Methylene blue dye from aqueous solution by novel activated Carbon based 
adsorbents," Progress in Color, Colorants and Coatings, vol. 12, pp. 133-144, 2019.

[63] L.-F. Chen, H.-H. Wang, K.-Y. Lin, J.-Y. Kuo, M.-K. Wang, and C.-C. Liu, "Removal of methylene blue from aqueous solution using sediment obtained from a canal in an industrial park," Water Science and Technology, vol. 78, no. 3, pp. 556-570, 2018.

[64] B. Acemioğlu, "Adsorption of Congo red from aqueous solution onto calcium-rich fly ash," Journal of Colloid and Interface Science, vol. 274, no. 2, pp. 371-379, 2004.

[65] M. Mohamed and S. Ouki, "Removal mechanisms of toluene from aqueous solutions by chitin and chitosan," Industrial \& Engineering Chemistry Research, vol. 50, no. 16, pp. 95579563, 2011.

[66] M. A. Al-Ghouti, A. Hawari, and M. Khraisheh, "A solidphase extractant based on microemulsion modified date pits for toxic pollutants," Journal of Environmental Management, vol. 130, pp. 80-89, 2013.

[67] O. Khelifi, I. Mehrez, W. Ben Salah et al., "Etude de l'adsorption du bleu de methylene (BM) a partir des solutions aqueuses sur un biosorbant prepare a partir des noyaux de datte algerienne," Larhyss Journal, vol. 28, pp. 135-148, 2016.

[68] F. Abed and K. Louhab, "Adsorption of methylene blue (MB) from aqueous solution using mixed sorbents prepared from date pit and olive stone," International Letters of Chemistry, Physics and Astronomy, vol. 51, pp. 94-104, 2015.

[69] S. Afshin, S. A. Mokhtari, M. Vosoughi, H. Sadeghi, and Y. Rashtbari, "Data of adsorption of Basic Blue 41 dye from aqueous solutions by activated carbon prepared from filamentous algae," Data in Brief, vol. 21, pp. 1008-1013, 2018.

[70] K. Mahmoudi, K. Hosni, N. Hamdi, and E. Srasra, "Kinetics and equilibrium studies on removal of methylene blue and methyl orange by adsorption onto activated carbon prepared from date pits-A comparative study," Korean Journal of Chemical Engineering, vol. 32, no. 2, pp. 274-283, 2014.

[71] C. Namasivayam and D. Kavitha, "Removal of Congo Red from water by adsorption onto activated carbon prepared from coir pith, an agricultural solid waste," Dyes and Pigments, vol. 54, no. 1, pp. 47-58, 2002.

[72] K. Imamura, E. Ikeda, T. Nagayasu, T. Sakiyama, and K. Nakanishi, "Adsorption behavior of methylene blue and its congeners on a stainless steel surface," Journal of Colloid and Interface Science, vol. 245, no. 1, pp. 50-57, 2002.

[73] C. Moreno-Castilla and J. Rivera-Utrilla, "Carbon materials as adsorbents for the removal of pollutants from the aqueous phase," MRS Bulletin, vol. 26, no. 11, pp. 890-894, 2001.

[74] V. K. Gupta and A. Rastogi, "Biosorption of hexavalent chromium by raw and acid-treated green alga Oedogonium hatei from aqueous solutions," Journal of Hazardous Materials, vol. 163, no. 1, pp. 396-402, 2009.

[75] S. Hazourli, G. Bonnecaze, and M. Astruc, "Adsorption et Electrosorption de Composes Organiques Sur Charbon Actif en Grains Partie I - influence du Potentiel Impose et du Nombre de Cycles Adsorption and Electrosorption of Organic Compounds on Granular Activated Carbon Part I - influence of Applied Potential and Number of Cycles," Environmental Technology, vol. 17, no. 12, pp. 1275-1283, 1996.

[76] N. A. Rahmat, A. A. Ali, Salmiati et al., "Removal of remazol brilliant blue $\mathrm{R}$ from aqueous solution by adsorption using pineapple leaf powder and lime peel powder," Water, Air, \& Soil Pollution, vol. 227, no. 4, 2016.

[77] B. T. Pelosi, L. K. S. Lima, and M. G. A. Vieira, "Removal of the synthetic dye remazol brilliant blue $r$ from textile industry wastewaters by biosorption on the macrophyte Salvinia natans," Brazilian Journal of Chemical Engineering, vol. 31, no. 4, pp. 1035-1045, 2014.

[78] M. R. Mafra, L. Igarashi-Mafra, D. R. Zuim, É. C. Vasques, and M. A. Ferreira, "Adsorption of remazol brilliant blue on an orange peel adsorbent," Brazilian Journal of Chemical Engineering, vol. 30, no. 3, pp. 657-665, 2013. 